\title{
Confocal Laser Endomicroscopy in the Diagnosis of Biliary and Pancreatic Disorders: A Systematic Analysis
}

\author{
Do Han Kim', Somashekar G. Krishna ${ }^{2}$, Emmanuel Coronel ${ }^{3}$, Paul T. Kröner ${ }^{4}$, Herbert C. Wolfsen ${ }^{4}$, Michael B. Wallace ${ }^{4}$, and Juan E. \\ Corral $^{5}$ \\ ${ }^{1}$ Universidad Francisco Marroquin, School of Medicine, Guatemala City, Guatemala, ${ }^{2}$ Division of Gastroenterology, Hepatology, and \\ Nutrition, The Ohio State University Wexner Medical Center, Columbus, Ohio, ${ }^{3}$ Division of Gastroenterology and Hepatology, MD \\ Anderson Cancer Center, Houston, Texas, ${ }^{4}$ Division of Gastroenterology and Hepatology, Mayo Clinic, Jacksonville, Florida, ${ }^{5}$ Division \\ of Gastroenterology and Hepatology, Presbyterian Health Services, Albuquerque, New Mexico, USA.
}

Background/Aims: Endoscopic visualization of the microscopic anatomy can facilitate the real-time diagnosis of pancreatobiliary disorders and provide guidance for treatment. This study aimed to review the technique, image classification, and diagnostic performance of confocal laser endomicroscopy (CLE).

Methods: We conducted a systematic review of CLE in pancreatic and biliary ducts of humans, and have provided a narrative of the technique, image classification, diagnostic performance, ongoing research, and limitations.

Results: Probe-based CLE differentiates malignant from benign biliary strictures (sensitivity, $\geq 89 \%$; specificity, $\geq 61 \%$ ). Needlebased CLE differentiates mucinous from non-mucinous pancreatic cysts (sensitivity, 59\%; specificity, $\geq 94 \%$ ) and identifies dysplasia. Pancreatitis may develop in 2-7\% of pancreatic cyst cases. Needle-based CLE has potential applications in adenocarcinoma, neuroendocrine tumors, and pancreatitis (chronic or autoimmune). Costs, catheter lifespan, endoscopist training, and interobserver variability are challenges for routine utilization.

Conclusions: CLE reveals microscopic pancreatobiliary system anatomy with adequate specificity and sensitivity. Reducing costs and simplifying image interpretation will promote utilization by advanced endoscopists. Clin Endosc 2022;55:197-207

Key Words: Biliary stricture; Cholangiocarcinoma; Confocal microscopy; Endoscopy; Pancreatic cyst

\section{INTRODUCTION}

Endomicroscopy refers to the use of different imaging technologies to microscopically evaluate the epithelium in real time. Electronic spectral enhancement and topical dyes are used to evaluate mucosal changes and identify superficial gastrointestinal neoplasia. Technologies such as narrow band imaging (Olympus Medical Systems Corp., Tokyo, Japan), iScan

Received: February 22, 2021 Revised: April 15, 2021

Accepted: May 10, 2021

Correspondence: Juan E. Corral

Division of Gastroenterology and Hepatology, Presbyterian Healthcare Services, 1100 Lead Avenue SE, Albuquerque, NM 87106, USA

Tel: +1-505-224-7000, Fax: +1-505-224-7292, E-mail: jcorralhu@phs.org

ORCID: https://orcid.org/0000-0002-8821-4534

cc This is an Open Access article distributed under the terms of the Creative Commons Attribution Non-Commercial License (http://creativecommons.org/ licenses/by-nc/3.0) which permits unrestricted non-commercial use, distribution, and reproduction in any medium, provided the original work is properly cited.
(Pentax Inc., Tokyo, Japan), and blue light/blue laser imaging (Fujinon Intelligent Chromo Endoscopy, Fujinon, Saitama, Japan) help separate the areas of metaplasia, dysplasia, and early neoplasia from normal mucosa in the gastroesophageal junction, stomach, and colon. ${ }^{1}$ With a higher magnification power, optical coherence tomography and volumetric laser endomicroscopy provide images of different histologic layers and cellular changes of the gastrointestinal epithelium and are useful for evaluating Barrett's esophagus. ${ }^{2}$ The diameters of the biliary and pancreatic ducts in normal conditions are significantly smaller than the rest of the gastrointestinal tract, making the evaluation of the biliary epithelium and pancreatic parenchyma particularly challenging using conventional optical devices.

Confocal laser endomicroscopy (CLE) uses intravenous fluorophore, fluorescein, and a fiber-optic confocal laser to achieve higher magnification and reveal cellular and subcellular structures in the epithelium (Fig. 1). Multiple applications 


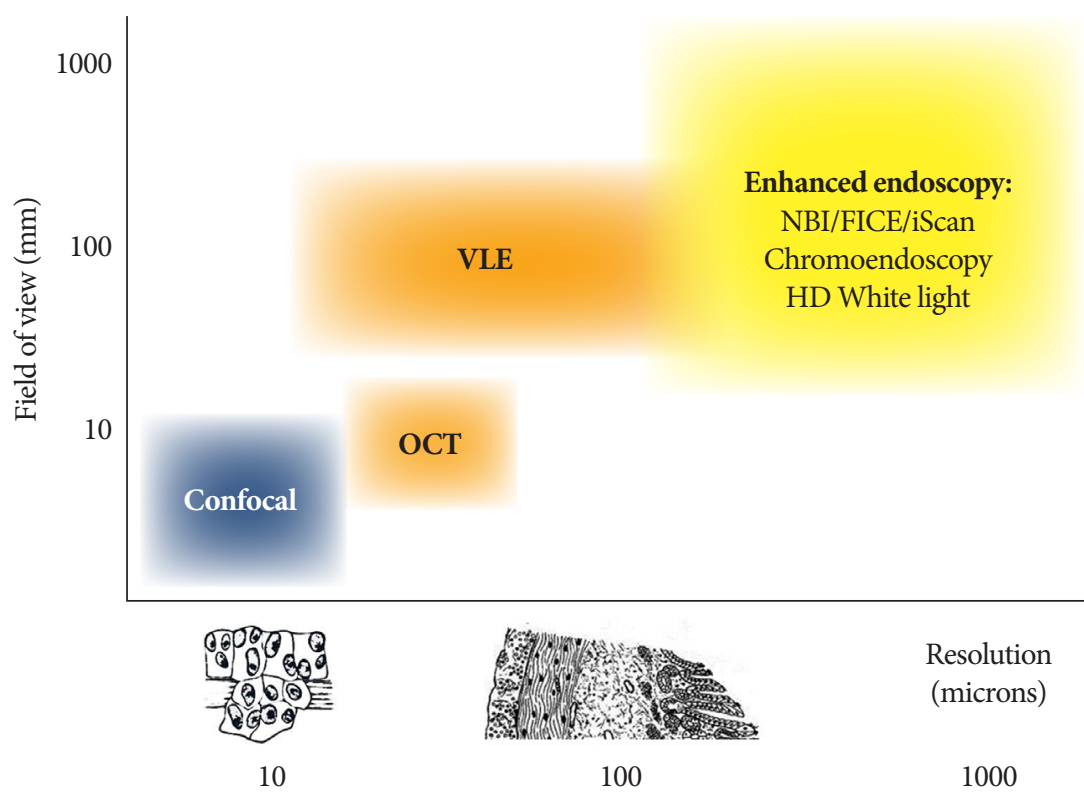

Fig. 1. Comparison of available endomicroscopy imaging technologies. FICE, Fujinon Intelligent Chromo Endoscopy (Fujinon, Saitama, Japan); HD, hight definition; iScan (Pentax Inc., Tokyo, Japan)); NBI, narrow band Imaging (Olympus Medical Systems Corp., Tokyo, Japan); OCT, optical coherence tomograpy; VLE, volumetric laser endomicroscopy. Courtesy of Dr. Wallace MB.

of CLE have been described across gastrointestinal luminal neoplasia, including increasing the detection of dysplasia in Barrett's esophagus, categorizing early gastric cancer, identifying dysplasia associated with inflammatory bowel disease, and revealing early cancer in colon polyps or surgical margins..$^{3-6}$ CLE has also been evaluated in benign conditions, including identifying mucosal atrophy in gastritis, measuring vascular integrity in celiac disease, determining mucosal permeability in inflammatory bowel disease, and visualizing inflammation in irritable bowel syndrome. ${ }^{7-11}$

Small-caliber CLE catheters are introduced into the biliary and pancreatic structures through endoscopic retrograde cholangiopancreatography (ERCP) or endoscopic ultrasonography (EUS). Malignant biliary strictures are traditionally evaluated using a combination of cross-sectional imaging, cytology brushings, and biopsies with micro forceps. Pancreatic cysts are characterized using a combination of cross-sectional imaging, EUS, and fluid analysis. However, this approach has some limitations, particularly in chronic inflammatory conditions such as primary sclerosing cholangitis. ${ }^{12,13}$ Over the last 20 years, interest has grown in using CLE imaging during endoscopy to facilitate evaluation of the biliary and pancreatic structures. This structured review aims to provide a clinical assessment of current applications of CLE in biliary and pancreatic disorders, summarize diagnostic performance in both areas, and present the most recent criteria for image interpretation.

\section{METHODS}

The literature databases PubMed (US National Library of Medicine), Cochrane (The Cochrane Collaboration), and ClinicalTrials.gov (US National Institutes of Health) were reviewed. The search was performed in PubMed using two queries: Confocal microscopy (Medical Subject Headings [MeSH] term) OR Confocal laser scanning microscopy (MeSH) AND Endoscopy (non-MeSH) AND Pancreas (non-MeSH); and Confocal microscopy (MeSH) OR Confocal laser scanning microscopy (MeSH) AND Endoscopy (non-MeSH) and Biliary (non-MeSH). The selected studies were limited to those including humans and those in the English language published through March 15, 2021. Analogous strategies were used to search the other two databases.

Two investigators, Do Han Kim and Paul T. Kröner, independently reviewed the titles and abstracts of the retrieved articles. For journal manuscripts, full-text articles were retrieved for further review. Titles that could not be associated with an abstract were excluded from review. All studies and case reports that addressed the CLE technique, image interpretation or classification, accuracy estimations (i.e., specificity and sensitivity), interobserver agreement, and consensus meetings were retrieved and reviewed individually. Studies that used biomarkers or imaging tests other than CLE (e.g., EUS, cytology) as the main diagnostic tool were removed. If two or more manuscripts studied the same patient population, the one pub- 
lished most recently or with the largest sample was selected. If two manuscripts provided complementary information (e.g., different years), both were included. If there was any discrepancy about whether a study should be included, a third investigator (Juan E. Corral) determined adequacy. When needed, the corresponding authors of the studies were contacted for additional information.

The following information was abstracted from each article: year of publication, first author, sample size, comparison groups, diagnostic accuracy, and adverse events (e.g., pancreatitis). Using the available information, we analyzed sensitivity, specificity, and diagnostic accuracy using conventional $2 \times 2$ tables.

We provide individual estimates of accuracy and opted not to perform a meta-analysis to illustrate the diversity of applications across different pathologies and patient subgroups. Furthermore, six meta-analyses have already been published on this topic, and their relevant results are included here. ${ }^{14-19}$

\section{RESULTS}

The initial literature search retrieved 47 publications in the biliary group and 25 publications in the pancreas group. A Cochrane search retrieved CLE applications in dermatology (i.e., evaluation of melanoma and basal cell carcinoma) and ophthalmology (i.e., evaluation of the optic nerve and glaucoma) but no applications in gastroenterology. A review of ClinicalTrials.gov identified 20 trials using CLE in the biliary ducts and 10 trials using CLE in the pancreas.

After the exclusion of 14 irrelevant publications and three duplicate publications (overlapping pancreatic and biliary duct evaluation), 55 full-text articles were subjected to further evaluation. Numbers in Fig. 2, may differ considering that review articles covered both pancreatic and biliary, studies found in Clinical trials.gov not included. No studies were excluded for having a small sample size (Fig. 2).

\section{CLE technique}

Thin confocal laser probes feature a small enough diameter
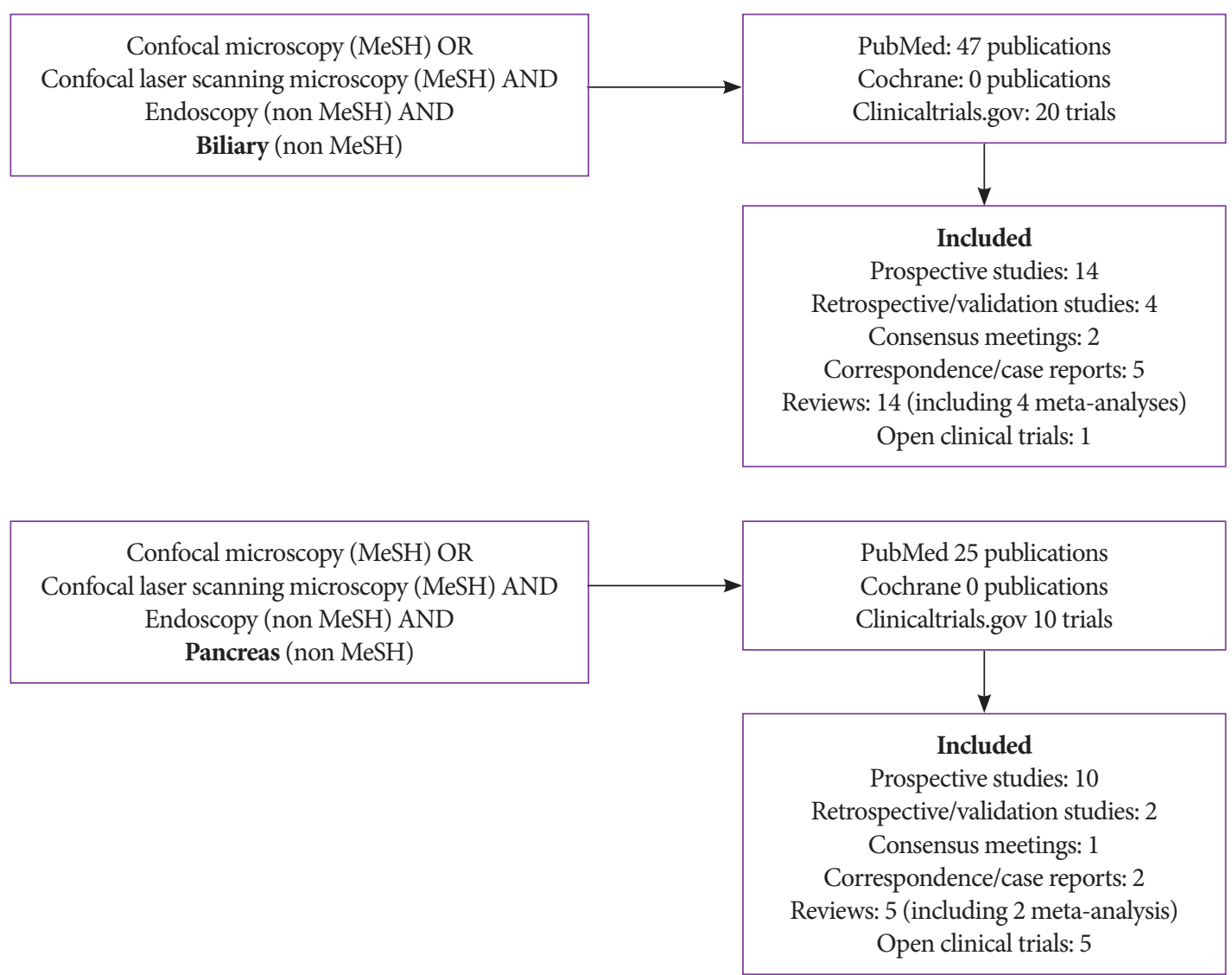

Fig. 2. Literature review flowchart. MeSH, medical subject headings used by the National Library of Medicine. 
to allow their insertion through the working channel of conventional endoscopes and advancement through endoscopy needles. These techniques allow navigation into the biliary and pancreatic ducts and evaluation of pancreatic cystic lesions. Imaging depth can be carefully controlled with fluoroscopy by a single operator.

Two commercial probes are now available, one of which has been cleared by the United States Food and Drug Administration for patient care (Cellvizio, Mauna Kea Technologies, Paris, France). ${ }^{11}$ Similar to other confocal applications, fluorescein (2-5 mL; 10\% fluorescein sodium) is injected intravenously 2-3 minutes before imaging. Images are obtained placing the probe directly against the mucosa. The probe-based confocal laser endomicroscopy (pCLE) probe or "miniprobe" works through a 1-mm compatible operating channel. It was designed to be inserted through a side-viewing endoscope into the biliary ducts. The needle-based confocal laser endomicroscopy (nCLE) probe is slightly thinner and works through a compatible $0.95-\mathrm{mm}$ operating channel. It was designed to be advanced through a 19-gauge EUS needle into pancreatic cysts.

According to the manufacturer's instructions, both probes can be used up to 10 times. The probe tip is radio-opaque, allowing guidance and probe positioning under fluoroscopy. The optical penetration of the confocal plane provides superficial subsurface information without interference from bile or solid residues. Images feature high resolution at the cellular level. For both pCLE and nCLE, the manufacturer reports a field of view of $325 \mu \mathrm{m}$, resolution of $3.5 \mu \mathrm{m}$, and confocal depth of $40-70 \mu \mathrm{m}$. Changes in the tissue micro-architecture are used to visually differentiate between malignant and benign disorders (Fig. 1). Training for image recognition and interpretation takes approximately 6 hours for pCLE and 5 hours for nCLE. ${ }^{20,21}$ Three main applications were identified in our systematic review: indeterminate biliary strictures, pan- creatic cysts, and pancreatic parenchyma.

\section{Indeterminate biliary strictures}

Malignant biliary strictures (caused by cholangiocarcinoma, hepatocellular carcinoma, or metastatic cancer to the liver) can be difficult to differentiate from benign strictures (caused by inflammation, surgical scaring, or extrinsic compression). Up to $15 \%$ of patients who undergo surgical resection for suspected malignancy end up having a benign condition. ${ }^{22}$

When a biliary stricture is identified, the conventional approach is ERCP with bile duct brushings for cytology, fluorescence in-situ hybridization analysis for trisomy/polysomy, and cholangioscopy with targeted biopsies for histology. This triple approach has a sensitivity of $89 \%$ and a specificity of $96 \%$ for identifying cancer. ${ }^{23}$ In these patients, pCLE is an adjunct tool for differentiating benign from malignant biliary strictures. Once the biliary stricture is located by the injection of radiopaque contrast, the pCLE catheter is passed through the narrow area while a black and white histology video is recorded. Images can be interpreted in real time or reviewed later by freezing frames for better interpretation. After pCLE videos are collected, the conventional brushings and biopsies can be performed.

\section{Diagnostic criteria and performance}

Image interpretation of pCLE is based on bands, shadows, and background colors that reflect changes in vascular patterns and epithelial cells. White bands correspond to lymphatic or blood vessels, while dark bands correspond to collagen fibrils that clump into tumoral glands. ${ }^{24}$ An expert meeting proposed the initial criteria for the interpretation of CLE biliary images in 2011 (Miami classification). ${ }^{25}$ Two years later, a second meeting refined the criteria and increased their specificity and accuracy (Paris classification; Table 1). ${ }^{26}$ In this system, the bile ducts are classified as normal, inflammatory strictures, or ma-

Table 1. Paris Classification of Probe-Based Confocal Laser Endomicroscopy Patterns in Biliary Ducts

\begin{tabular}{llll}
\hline & Healthy bile duct & Inflammatory stricture & Malignant stricture \\
\hline Collagen fibrils & $\begin{array}{l}\text { Reticular network of thin dark } \\
\text { branching bands }(<20 \mu \mathrm{m})\end{array}$ & $\begin{array}{l}\text { Dark granular pattern in scales } \\
\text { Thickened reticular structures }\end{array}$ & Thick dark bands $(>40 \mu \mathrm{m})$ \\
Background & Light grey & Roughness aspect & Dark clumps \\
Vessels & Thin white bands $(<20 \mu \mathrm{m})$ & Vascular congestion & Thick white bands $(>20 \mu \mathrm{m})$ \\
Epithelium & & $\begin{array}{l}\text { Enlarged space between scales } \\
\text { Increased inter-glandular space }\end{array}$ & Epithelium visualized (villi, glands) \\
Additional features & & & Fluorescein leakage \\
\hline
\end{tabular}

${ }^{\text {a) }}$ Suggested in the Miami classification but not included in the Paris classification. ${ }^{24,25}$ 


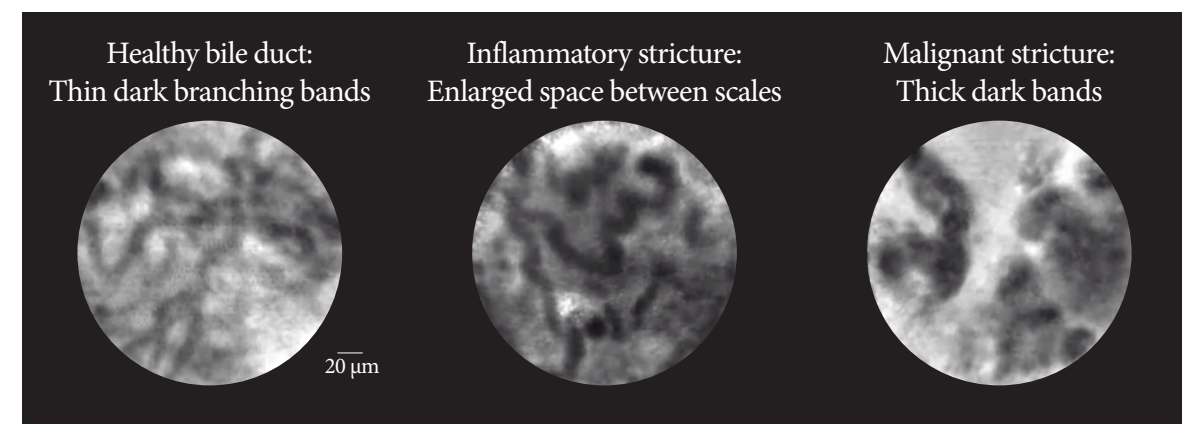

Fig. 3. Representative patterns of probe-based confocal laser endomicroscopy in biliary ducts conditions. Courtesy of Mauna Kea Technologies, Inc.

lignant strictures (Fig. 3).

An international consensus in 2015 reported that PCLE is more accurate than ERCP with brush cytology and/or forceps biopsy for discriminating malignant from benign strictures using established criteria ( $87 \%$ agreement). ${ }^{27}$ ERCP-guided pCLE is now mentioned as an adjunct tool by the American Society of Gastrointestinal Endoscopy for management of patients with indeterminate biliary strictures. ${ }^{28} \mathrm{~A}$ technical review from the European Society of Gastrointestinal Endoscopy recognized that pCLE is currently difficult and expensive but has the potential to become an important diagnostic tool for indeterminate biliary strictures. ${ }^{29}$

The diagnostic performance of pCLE in indeterminate biliary strictures is demonstrated in Table 2. Among the 46

Table 2. Landmark Studies Evaluating Probe-based Confocal Laser Endomicroscopy in Biliary Strictures

\begin{tabular}{|c|c|c|c|c|c|c|c|}
\hline \multicolumn{8}{|c|}{ Biliary strictures } \\
\hline Study & Aim & Study design & Sensitivity & Specificity & Accuracy & Pancreatitis & Comments \\
\hline $\begin{array}{l}\text { Meining et al. } \\
(2011),{ }^{24} n=86^{\mathrm{a})}\end{array}$ & $\begin{array}{l}\text { Diagnosis of } \\
\text { cholangiocarci- } \\
\text { noma. }\end{array}$ & $\begin{array}{l}\text { Prospective mul- } \\
\text { ticenter }\end{array}$ & $98 \%$ & $67 \%$ & $81 \%$ & $0 \%$ & $\begin{array}{l}3 \text { pancreatic } \\
\text { strictures included }\end{array}$ \\
\hline $\begin{array}{l}\text { Heif et al. }(2013)^{30}, \\
n=15\end{array}$ & $\begin{array}{l}\text { Dominant stric- } \\
\text { ture in PSC. }\end{array}$ & $\begin{array}{l}\text { Case series single } \\
\text { center }\end{array}$ & $100 \%$ & $61 \%$ & $66 \%$ & $0 \%$ & PSC only \\
\hline $\begin{array}{l}\text { Caillol et al. } \\
(2013),{ }^{26} n=60\end{array}$ & $\begin{array}{l}\text { Standardize } \\
\text { image interpre- } \\
\text { tation }\end{array}$ & $\begin{array}{l}\text { Retrospective } \\
\text { image review }\end{array}$ & $96 \%$ & $76 \%$ & $85 \%$ & NA & $\begin{array}{l}\text { Focused on image } \\
\text { standardization }\end{array}$ \\
\hline $\begin{array}{l}\operatorname{EMID}(2015),{ }^{31} \\
n=61^{\text {a) }}\end{array}$ & $\begin{array}{l}\text { Malignant vs. } \\
\text { benign strictures }\end{array}$ & $\begin{array}{l}\text { Prospective single } \\
\text { center }\end{array}$ & $100 \%$ & $71 \%$ & $93 \%$ & NA & $\begin{array}{l}\text { Added EUS-guided } \\
\text { biopsies }\end{array}$ \\
\hline $\begin{array}{l}\text { FOCUS }(2015),{ }^{32} \\
n=112\end{array}$ & $\begin{array}{l}\text { Malignant vs. } \\
\text { benign strictures }\end{array}$ & $\begin{array}{l}\text { Prospective mul- } \\
\text { ticenter }\end{array}$ & $89 \%$ & $71 \%$ & $82 \%$ & $0 \%$ & $\begin{array}{l}\text { Excluded patients } \\
\text { with PSC }\end{array}$ \\
\hline $\begin{array}{l}\text { Fugazza et al. } \\
(2016),{ }^{18} \\
10 \text { studies, } n=494\end{array}$ & $\begin{array}{l}\text { Malignant vs. } \\
\text { benign strictures }\end{array}$ & $\begin{array}{l}\text { Systematic review } \\
\text { and meta-analy- } \\
\text { sis }\end{array}$ & Pooled $90 \%$ & $\begin{array}{c}\text { Pooled } \\
72 \%\end{array}$ & $\begin{array}{l}\text { Pooled } \\
81 \%\end{array}$ & NA & $\begin{array}{l}\text { Also reviewed } \\
\text { Barrett's, gastric } \\
\text { and colorectal } \\
\text { cancer }\end{array}$ \\
\hline $\begin{array}{l}\text { Liu et al. }(2016),{ }^{17} \\
8 \text { studies, } n=280\end{array}$ & $\begin{array}{l}\text { Malignant vs. } \\
\text { benign strictures }\end{array}$ & $\begin{array}{l}\text { Systematic review } \\
\text { and meta-analy- } \\
\text { sis }\end{array}$ & Pooled 90\% & $\begin{array}{l}\text { Pooled } \\
75 \%\end{array}$ & $\begin{array}{c}\text { Pooled } \\
82 \%\end{array}$ & NA & \\
\hline $\begin{array}{l}\text { Dubow et al. } \\
(2018),{ }^{33} n=97\end{array}$ & $\begin{array}{l}\text { Malignant vs. } \\
\text { benign strictures }\end{array}$ & $\begin{array}{l}\text { Retrospective } \\
\text { single center }\end{array}$ & $83 \%$ & $93 \%$ & $90 \%$ & NA & $\begin{array}{l}\text { Prior ERCP } \\
\text { sampling and } \\
\text { imaging negative }\end{array}$ \\
\hline $\begin{array}{l}\text { Koda et al. } \\
(2021),{ }^{34} n=7\end{array}$ & $\begin{array}{l}\text { Malignant vs. } \\
\text { benign strictures }\end{array}$ & $\begin{array}{l}\text { Case series single } \\
\text { center }\end{array}$ & $\begin{array}{l}\text { GastroFlex }^{\mathrm{TM}} \\
100 \% \\
\text { CholangioFlex } \\
75 \% \\
\text { AlveoFlex }^{\mathrm{TM}} 75 \%\end{array}$ & $\begin{array}{c}0 \%(0 / 3) \\
66.7 \% \\
33.3 \%\end{array}$ & $\begin{array}{l}57.1 \% \\
71.4 \% \\
57.1 \%\end{array}$ & NA & \\
\hline
\end{tabular}

${ }^{a)}$ In cases of multiple manuscripts published by the same group, we selected the most recent publication or the one with the largest sample. ERCP, endoscopic retrograde cholangiopancreatography; EUS, endoscopic ultrasonography; NA, not available; nCLE, needle-based confocal laser endomicroscopy; pCLE, probe-based confocal laser endomicroscopy; PSC, primary sclerosing cholangitis. 
Table 3. Landmark Studies Evaluating Needle-based Confocal Endomicroscopy in Pancreatic Cysts and Solid Lesions

\begin{tabular}{|c|c|c|c|c|c|c|c|}
\hline \multicolumn{8}{|c|}{ Pancreatic cysts } \\
\hline Study & Aim & Study design & Sensitivity & Specificity & Accuracy & Pancreatitis & Comments \\
\hline $\begin{array}{l}\text { INSPECT }(2013),{ }^{35} \\
n=57\end{array}$ & $\begin{array}{l}\text { SCA and pseudo- } \\
\text { cyst vs. other cysts }\end{array}$ & $\begin{array}{l}\text { Prospective } \\
\text { multicenter }\end{array}$ & $59 \%$ & $100 \%$ & $71 \%$ & $3 \%$ & $\begin{array}{l}\text { Early phase defining } \\
\text { diagnostic criteria }\end{array}$ \\
\hline $\begin{array}{l}\text { DETECT }(2015),{ }^{36} \\
n=29\end{array}$ & $\begin{array}{l}\text { Mucinous vs. other } \\
\text { cysts }\end{array}$ & $\begin{array}{l}\text { Prospective single } \\
\text { center }\end{array}$ & $80 \%$ & $100 \%$ & $89 \%$ & $7 \%$ & $\begin{array}{l}\text { Combination with } \\
\text { cystoscopy yields } \\
100 \% \text { accuracy }\end{array}$ \\
\hline $\begin{array}{l}\text { Fugazza et al. } \\
(2016){ }^{18} \\
5 \text { studies, } n=163\end{array}$ & $\begin{array}{l}\text { Malignancy in } \\
\text { pancreatic cysts }\end{array}$ & $\begin{array}{l}\text { Systematic review } \\
\text { and meta-analysis }\end{array}$ & Pooled 68\% & Pooled $90 \%$ & $\begin{array}{c}\text { Pooled } \\
79 \%\end{array}$ & NA & $\begin{array}{l}\text { Also reviewed Bar- } \\
\text { rett's, gastric and } \\
\text { colorectal cancer }\end{array}$ \\
\hline $\begin{array}{l}\text { CONTACT } \\
(2015){ }^{37} \\
n=43(\text { included } 31)\end{array}$ & SCA vs. other cysts & $\begin{array}{l}\text { Prospective } \\
\text { multicenter }\end{array}$ & $\begin{array}{c}\text { SCA 95\% } \\
\text { Indeterminate } \\
\text { mucinous 95\% } \\
\text { NET 100\% } \\
\text { Premalignant } \\
\text { cyst 96\% }\end{array}$ & $\begin{array}{c}100 \% \\
100 \% \\
95 \% \\
95 \%\end{array}$ & $\begin{array}{l}99 \% \\
97 \% \\
96 \% \\
96 \%\end{array}$ & $2 \%$ & $\begin{array}{l}\text { Superior than } \\
\text { combination of } \\
\text { CEA and cytology } \\
\text { analysis }\end{array}$ \\
\hline $\begin{array}{l}\operatorname{INDEX}(2019),{ }^{38} \\
n=144\end{array}$ & $\begin{array}{l}\text { Mucinous vs. non } \\
\text { mucinous pancre- } \\
\text { atic cysts }\end{array}$ & $\begin{array}{l}\text { Prospective single } \\
\text { center }\end{array}$ & $98 \%$ & $94 \%$ & $97 \%$ & $3 \%$ & $\begin{array}{l}\text { Superior than } \\
\text { combination of } \\
\text { CEA and cytology } \\
\text { analysis }\end{array}$ \\
\hline $\begin{array}{c}\text { CONCYST (2019), }{ }^{39} \\
n=67 \text { (included 56) }\end{array}$ & $\begin{array}{l}\text { Indeterminate } \\
\text { pancreatic cyst }\end{array}$ & $\begin{array}{l}\text { Prospective } \\
\text { multicenter }\end{array}$ & $\begin{array}{l}\text { All indeterminate } \\
\text { cysts } 80 \% \\
\text { IPMN } 90 \% \\
\text { Ductal adenocar- } \\
\text { cinoma } 100 \% \\
\text { SCA } 56 \% \\
\text { Pseudocysts } 67 \%\end{array}$ & NA & $\begin{array}{c}77 \% \\
87 \% \\
100 \% \\
38 \% \\
67 \%\end{array}$ & $0 \%$ & $\begin{array}{l}\text { Correlation with } \\
\text { pathology and } \\
\text { experts was good. } \\
\text { Image acquisition } \\
\text { took }<10 \text { min }\end{array}$ \\
\hline $\begin{array}{l}\text { Krishna et al. } \\
(2020),{ }^{38,40} \\
n=26\end{array}$ & $\begin{array}{l}\text { Identify dysplasia } \\
\text { in IPMN }\end{array}$ & $\begin{array}{l}\text { INDEX post-hoc } \\
\text { analysis }\end{array}$ & $\begin{array}{l}\text { Papillary epitheli- } \\
\text { al width } 88 \% \\
\text { Papillary epitheli- } \\
\text { al darkness } 88 \%\end{array}$ & $\begin{array}{l}100 \% \\
100 \%\end{array}$ & $\begin{array}{l}85 \% \\
84 \%\end{array}$ & $3 \%$ & $\begin{array}{l}\text { Allow risk stratifica- } \\
\text { tion of IPMN }\end{array}$ \\
\hline $\begin{array}{l}\text { Hao et al. }(2020),{ }^{41} \\
n=122\end{array}$ & $\begin{array}{l}\text { Solid and cystic } \\
\text { pancreatic lesions }\end{array}$ & $\begin{array}{l}\text { Prospective single } \\
\text { center }\end{array}$ & $\begin{array}{l}\text { All cysts } 94 \% \\
\text { SCA } 89 \% \\
\text { MCN } 87 \% \\
\text { IPMN 97\% }\end{array}$ & $\begin{array}{c}98 \% \\
100 \% \\
98 \% \\
100 \%\end{array}$ & $\begin{array}{l}97 \% \\
97 \% \\
94 \% \\
99 \%\end{array}$ & $5 \%$ & \\
\hline $\begin{array}{l}\text { Facciorusso et al. } \\
(2020){ }^{15} \\
10 \text { studies, } n=536\end{array}$ & $\begin{array}{l}\text { Pancreatic cystic } \\
\text { lesions }\end{array}$ & $\begin{array}{l}\text { Systematic review } \\
\text { and meta-analysis }\end{array}$ & Pooled $82 \%$ & Pooled 97\% & $89 \%$ & $0 \%$ & $\begin{array}{l}\text { Mean procedure } \\
\text { duration of } 6 \mathrm{mins}\end{array}$ \\
\hline $\begin{array}{l}\text { Konjeti et al. } \\
(2020){ }^{19} \\
7 \text { studies, } n=324\end{array}$ & $\begin{array}{l}\text { Pancreatic cystic } \\
\text { lesions }\end{array}$ & $\begin{array}{l}\text { Systematic review } \\
\text { and meta-analysis }\end{array}$ & Pooled $85 \%$ & $99 \%$ & $99 \%$ & $1 \%$ & $\begin{array}{l}\text { High heterogeneity } \\
\text { among studies }\end{array}$ \\
\hline $\begin{array}{l}\text { Chin et al. }(2021),{ }^{42} \\
42 \text { studies, } n=519\end{array}$ & $\begin{array}{l}\text { Pancreatic cystic } \\
\text { lesions }\end{array}$ & Systematic review & & & & $2.6 \%$ & $\begin{array}{l}\text { No meta-analysis } \\
\text { performed }\end{array}$ \\
\hline \multicolumn{8}{|c|}{ Pancreatic parenchyma and solid lesions } \\
\hline $\begin{array}{l}\text { Giovannini et al. } \\
(2016){ }^{43} \\
n=40\end{array}$ & $\begin{array}{l}\text { Solid pancreatic } \\
\text { lesions, compared } \\
\text { to pathology }\end{array}$ & $\begin{array}{l}\text { Prospective } \\
\text { multicenter. Part of } \\
\text { CONTACT }\end{array}$ & $\begin{array}{l}\text { Ductal adenocar- } \\
\text { cinoma } 77 \% \\
\text { Chronic } \\
\text { pancreatitis 50\% } \\
\text { NET } 100 \%\end{array}$ & $\begin{array}{c}100 \% \\
100 \% \\
97 \%\end{array}$ & $\begin{array}{l}85 \% \\
91 \% \\
97 \%\end{array}$ & NA & $\begin{array}{l}\text { First description of } \\
\text { adenocarcinoma, } \\
\text { NET and chronic } \\
\text { pancreatitis }\end{array}$ \\
\hline $\begin{array}{l}\text { Hao et al. }(2020),{ }^{41} \\
n=50\end{array}$ & $\begin{array}{l}\text { Solid and cystic } \\
\text { pancreatic lesions }\end{array}$ & $\begin{array}{l}\text { Prospective single } \\
\text { center }\end{array}$ & $\begin{array}{l}\text { Ductal adenocar- } \\
\text { cinoma } 90 \%\end{array}$ & $89 \%$ & $90 \%$ & $5 \%$ & $\begin{array}{l}\text { First description of } \\
\text { AIP and } \\
\text { tuberculosis }\end{array}$ \\
\hline
\end{tabular}

AIP, autoimmune pancreatitis; CEA, carcinoembryonic antigen; IPMN, intraductal papillary mucinous neoplasm; NA, not available; nCLE, needle-based confocal laser endomicroscopy; NET, neuroendocrine tumor; pCLE, probe-based confocal laser endomicroscopy; SCA, serous cystadenoma. 
publications identified in the literature, nine were considered relevant. Sensitivity ranged from $75 \%$ to $100 \%$ and specificity ranged from $0 \%$ (one small study with three participants) to 93\%. Overall, pCLE has a great negative predictive value for cancer in indeterminate biliary strictures. The negative predictive value of pCLE was estimated to be $94 \%$, those of biliary biopsies (78\%), biliary brushings (77\%), and ERCP overall $(98 \%) .{ }^{33}$ In fact, pCLE has additional value for patients with primary sclerosing cholangitis (PSC), who experience progressive inflammation of the bile ducts and develop cholangiocarcinoma at high rates (1.5\% incidence per year). Distinguishing cholangiocarcinoma from other inflammatory strictures in PSC remains challenging. Compared to other indications, the sensitivity of the traditional triple approach (fluorescence in-situ hybridization, cytology brushings, and biopsies) in PSC is only $54 \%$, but it increases to $61 \%$ after the addition of pCLE (specificity and accuracy remain $>80 \%$, while the negative predictive value is 100 [95\% confidence interval, $71.3-100]$ ). ${ }^{30}$

\section{Pancreatic cysts}

Pancreatic cysts are easily visualized with EUS, and special needles are introduced into them to collect fluid for tumor marker and cytology testing. Once a 19-gauge needle is inserted into a pancreatic cyst, an nCLE probe is advanced under EUS guidance into the pancreatic cyst. An intracystic endomicroscopic video is captured with permissive angulation of the needle facilitated by the elevator of the ecoendoscope using axial rotation of the endoscopist or the gentle application of torque. After the image collection, the nCLE probe is withdrawn and the cyst can be aspirated. The cystic fluid is evaluated for cytology, amylase, and carcinoembryonic antigen levels, mutations in tumor suppressor genes (loss of heterozygosity), and oncogene point mutations. If desired, a small-caliber biopsy forceps (Moray micro forceps, US Endoscopy, Mentor, Ohio, USA) can also be advanced through the needle channel to enable additional biopsies of the cyst wall. ${ }^{44}$ At the end of the procedure, intravenous antibiotic prophylaxis is administered to prevent cyst infection.

Of note, using the same technique as for bile duct evaluation, a pCLE probe can be introduced into the pancreatic duct for the evaluation of malignant pancreatic strictures or main duct-intraductal mucinous neoplasms (IPMN). ${ }^{24}$

\section{Diagnostic criteria and performance}

It is noteworthy that nCLE was not reviewed at the consensus meeting in 2015 or the most recent European Society of Gastrointestinal Endoscopy technology review. ${ }^{27,29}$ The 2016 American Society of Gastrointestinal Endoscopy guideline for managing cystic pancreatic neoplasms acknowledged that the addition of nCLE increases the diagnostic yield of serous cystic neoplasms with high interobserver agreement. ${ }^{45}$ Landmark studies evaluating nCLE in pancreatic cysts and solid lesions are shown in Table 3.

Comprehensive diagnostic criteria for nCLE in the evaluation of pancreatic cysts were established in the CONTACT and the INDEX studies. ${ }^{37,38,40}$ Its diagnostic features are divided into epithelial patterns and vascular patterns (Table $4^{36,38}$ ). Specific patterns for different types of pancreatic cysts are shown in Fig. 4. The addition of nCLE can enable the classification of pancreatic cysts into mucinous cysts (IPMN or mucinous cystic neoplasms) and non-mucinous cysts (serous cystadenoma, pseudocyst, or solid tumors with a cystic component [e.g. neuroendocrine tumors]). A clear application of nCLE is identifying benign serous cystadenomas and thereby preventing unnecessary surgery in these patients. A recent study showed that nCLE can be used to identify dysplasia and localized cancer in cases of IPMN. After the implementation of the INDEX criteria, papillary width and darkness should be measured (Table 4$)^{40}$

Studies initially raised concerns that the addition of nCLE

Table 4. Needle-based Confocal Endomicroscopy

\begin{tabular}{|c|c|c|c|c|c|}
\hline \multicolumn{4}{|c|}{ Epithelial patterns } & \multicolumn{2}{|c|}{ Vascular patterns } \\
\hline \multicolumn{2}{|c|}{ Papillae or epithelial bands } & $\begin{array}{l}\text { Dark background } \\
\text { with bright particles }\end{array}$ & Trabecular pattern & $\begin{array}{l}\text { Branched or } \\
\text { rope-ladder pattern }\end{array}$ & $\begin{array}{l}\text { Fern pattern (in the absence } \\
\text { of any epithelial features) }\end{array}$ \\
\hline \multicolumn{2}{|c|}{$\begin{array}{l}\text { IPMN, MCN } \\
\text { Accuracy } 96 \%\end{array}$} & $\begin{array}{l}\text { Pseudocyst } \\
\text { Accuracy } 98 \%\end{array}$ & $\begin{array}{l}\text { Cystic-NET, SPT } \\
\text { Accuracy } 97 \%\end{array}$ & $\begin{array}{l}\text { IPMN, MCN } \\
\text { Accuracy } 75 \%\end{array}$ & $\begin{array}{c}\text { SCA } \\
\text { Accuracy } 99 \%\end{array}$ \\
\hline Papillae: IPMN & $\begin{array}{l}\text { Epithelial } \\
\text { chronic in } \\
\text { mation: }\end{array}$ & & & & \\
\hline \multicolumn{6}{|c|}{$\begin{array}{l}\text { High-grade dysplasia: Papillary width } \geq 50 \mu \mathrm{m} \\
\text { Papillary darkness } \leq \mathbf{9 0} \text { pixel intensity }\end{array}$} \\
\hline
\end{tabular}

IPMN, intraductal mucinous papillary neoplasm; MCN, mucinous cystic neoplasm; Ncle, needle-based confocal laser endomicroscopy; NET, neuroendocrine tumor; SCA, serous cystadenoma; SPT, solid pseudopapillary tumor. 


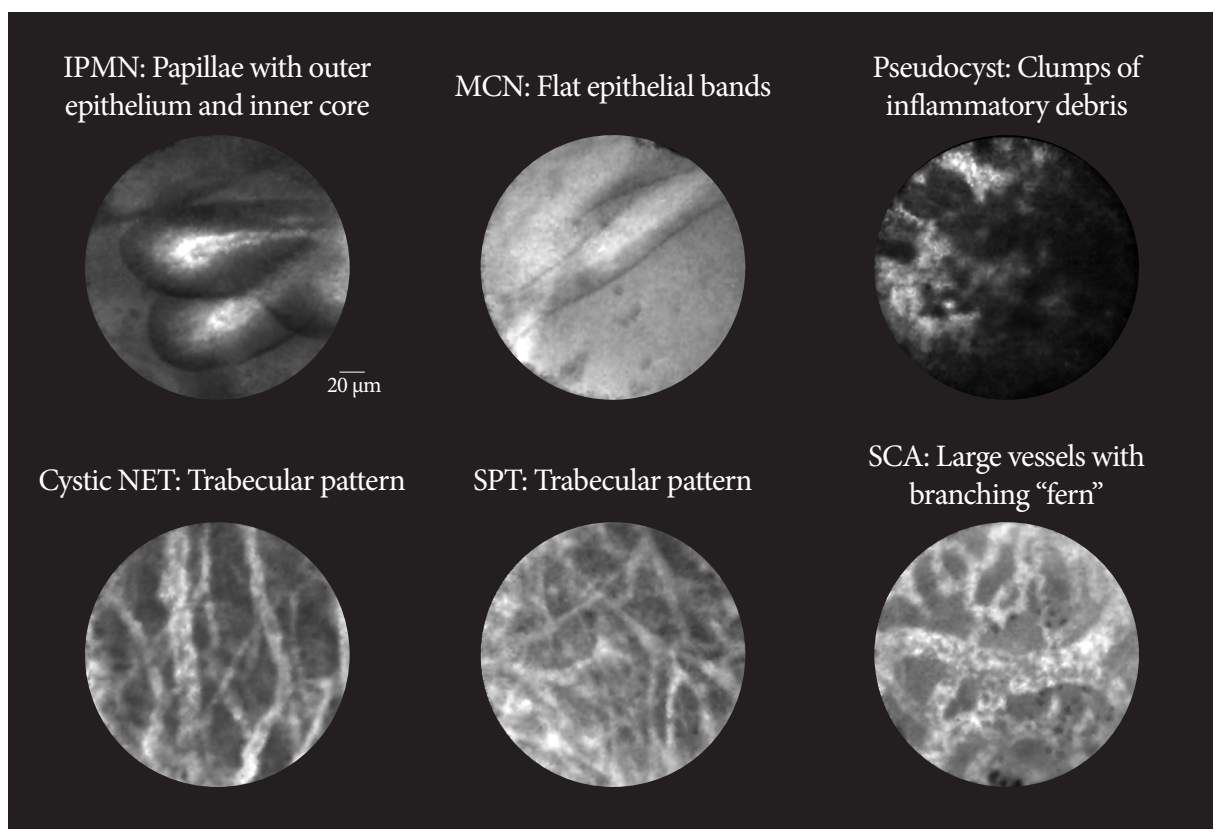

Fig. 4. Representative patterns of needle-based confocal laser endomicroscopy in pancreatic cysts. Pseudocyst can have a dark or light background. Cystic NET and SPT can only be differentiated using immunostaining. IPMN, intraductal mucinous papillary neoplasm; MCN, mucinous cystic neoplasm; NET, neuroendocrine tumor; SCA, serous cystadenoma; SPT, solid pseudopapillary tumor. Courtesy of Krishna SG.

to the traditional EUS aspiration of pancreatic cysts would increase the rate of adverse events (reported in 7-9\% of all cases). ${ }^{46}$ However, larger studies published over the last 10 years show reduced rates of pancreatitis similar to those seen for ERCP (Table 2). Other adverse events include bleeding into the cyst (1\%), pruritus (1.5\%), pseudocyst infection (1.5\%; one case reported resolved with antibiotics), and peri-pancreatic fluid collection (2\%). ${ }^{41,47}$

\section{Pancreatic parenchyma}

Two studies have evaluated the use of nCLE for the pancreatic parenchyma and solid tumors. ${ }^{41,43}$ Researchers in China and France described the general characteristics of pancreatic adenocarcinoma, neuroendocrine tumors, chronic pancreati- tis, autoimmune pancreatitis, solid pseudopapillary tumors, and one case of pancreatic tuberculosis (Table ${ }^{40,42}$ ). The reported performance and pancreatitis incidence was similar to that reported for nCLE for pancreatic cysts (Table 3). In the authors' experience, without the liquid interface of the cyst, images are static and image interpretation is challenging.

\section{DISCUSSION}

Implementation costs, catheter lifespan, sampling errors, interobserver variability, and added procedure time have limited the broader utilization of CLE in clinical practice. ${ }^{48}$ While CLE technology is being refined, alternative devices for tissue

Table 5. Initial Characteristics of Needle-Based Confocal Laser Endomicroscopy Patterns in Solid Pancreatic Tumors

\begin{tabular}{ll}
\hline & \multicolumn{1}{c}{ Findings } \\
\hline Adenocarcinoma & $\begin{array}{l}\text { Dark cell aggregates } \\
\text { Irregular vessels with fluorescein leakage }\end{array}$ \\
Chronic and autoimmune pancreatitis & $\begin{array}{l}\text { Residual regular glandular pancreatic structures } \\
\text { Massive fibrous areas }\end{array}$ \\
Neuroendocrine tumor & Black cell aggregates surrounded by vessels and fibrotic areas \\
Solid pseudopapillary tumor & Black columnar protrusions near the vascular area \\
Tuberculosis & Black huge cells (may correspond to macrophages) mixing with vesicular adipocytes \\
\hline
\end{tabular}


acquisition have been developed. ${ }^{49}$ For pancreatic cysts, micro forceps allow tissue sampling under direct EUS visualization. The risk of developing pancreatitis from an nCLE evaluation is similar to or lower than that of biopsies performed using micro forceps (2.1\%). ${ }^{49}$ The most cited limitation of both pCLE and nCLE is disagreement among expert endoscopists on image interpretation. Agreement was rated "poor" to "good" in three studies. ${ }^{20,50,51}$ Artificial intelligence systems have significant potential to resolve this issue.

Our review of ClinicalTrials.gov identified five clinical trials recruiting patients to receive CLE: three in China, one in Brazil, and one multicenter study in the United States. Two trials will evaluate patients with pancreatic cysts, two with patients requiring surgery (or percutaneous drainage) after pancreatic trauma, and one will utilize CLE for the early detection of different gastrointestinal tumors (Barrett's esophagus, partial gastric antrectomy, biliary duct strictures, pancreatic duct strictures, colorectal polyps, esophageal neoplasms, pancreatic head, and neck tumors). Significant limitations were found in studies evaluating its use for the pancreatic parenchyma or solid lesions.

Finally, early studies show that implementing deep learning algorithms into image recognition can facilitate CLE interpretation and expediate the clinical diagnosis. ${ }^{52,53}$ Despite the advances identified in our review, few studies have demonstrated that the use of CLE can change clinical decisions (e.g. prevent surgery) or improve direct patient care (e.g. shorten time to surgery or chemotherapy). ${ }^{37}$ Prospective trials able to prove such benefits will be instrumental in justifying the added cost of implementing CLE in regular clinical practice.

In conclusion, pCLE and nCLE enable the microscopic evaluation of the bile ducts and pancreas in vivo and in real time, enhancing the imaging arsenal of gastroenterologists. Integrating CLE into the endoscopy room along with conventional cytology, histology, and molecular testing improves cancer detection. Although our understanding of CLE microscopy continues to increase, patient outcomes data remain limited. CLE images remain subject to significant inter-reader reliability and sampling errors. Despite those limitations, most experts agree on the potential of CLE imaging and support its integration into future diagnostic algorithms. ${ }^{26,32}$

\section{Conflicts of Interest}

Juan E. Corral: Travel grant from AbbVie, Inc.; Minor food and beverage from Boston Scientific and Cook Medical.

Emmanuel Coronel: Consulting for Boston Scientific.

Michael B. Wallace: Consulting for Virgo Inc, Cosmo/Aries Pharmaceuticals, Anx Robotica (2019), Covidien, and GI Supply; Research grants from Fujifilm, Boston Scientific, Olympus, Medtronic, Ninepoint Medical, Cosmo/ Aries Pharmaceuticals; Stock options from Virgo Inc; Consulting on behalf of Mayo Clinic, GI Supply (2018), Endokey, Endostart,
Boston Scientific, and Microtek; General payments/minor food and beverage from Synergy Pharmaceuticals, Boston Scientific, and Cook Medical.

The authors have no potential conflicts of interest.

Funding

None.

\section{Author Contributions}

Conceptualization: Juan E. Corral

Data curation: Do Han Kim, Emmanuel Coronel, Paul T. Kröner

Formal analysis: DHK, EC, PTK

Funding acquisition

Investigation: DHK, EC, PTK

Methodology: JEC

Project administration: JEC

Resources: JEC

Supervision: JEC

Validation: Herbert C. Wolfsen, Michael B. Wallace

Visualization: Somashekar G Krishna, MBW

Writing-original draft: JEC

Writing-review \& editing: DHK, HCW, MBW

\section{ORCID}

Do Han Kim

Somashekar G. Krishna

Emmanuel Coronel

Paul T. Kröner

Herbert C. Wolfsen

Michael B. Wallace

Juan E. Corral https://orcid.org/0000-0002-2815-1105 https://orcid.org/0000-0001-5748-7890 https://orcid.org/0000-0001-8806-6765 https://orcid.org/0000-0002-7361-7883 https://orcid.org/0000-0002-6957-522X https://orcid.org/0000-0002-6446-5785 https://orcid.org/0000-0002-8821-4534

\section{REFERENCES}

1. Kochhar G, Wallace MB. Virtual histology in everyday gastrointestinal endoscopy. Clin Gastroenterol Hepatol 2018;16:1556-1561.

2. Trindade AJ, Leggett CL, Chang KJ. Volumetric laser endomicroscopy in the management of Barrett's esophagus. Curr Opin Gastroenterol 2017;33:254-260

3. Al-Mansour MR, Caycedo-Marulanda A, Davis BR, et al. SAGES TAVAC safety and efficacy analysis confocal laser endomicroscopy. Surg Endosc 2021;35:2091-2103.

4. Glover B, Teare J, Patel N. The status of advanced imaging techniques for optical biopsy of colonic polyps. Clin Transl Gastroenterol 2020;11:e00130.

5. Ruff S, Curtin B, Quezado M, et al. Evaluation of confocal endoscopic microscopy for detection of early-stage gastric cancer in hereditary diffuse gastric cancer (HDGC) syndrome. J Gastrointest Oncol 2019;10:407411.

6. Su P, Liu Y, Lin S, et al. Efficacy of confocal laser endomicroscopy for discriminating colorectal neoplasms from non-neoplasms: a systematic review and meta-analysis. Colorectal Dis 2013;15:e1-e12.

7. Yu X, Chen J, Zheng L, Song J, Lin R, Hou X. Quantitative diagnosis of atrophic gastritis by probe-based confocal laser endomicroscopy. Biomed Res Int 2020;2020:9847591.

8. Buchner AM. Confocal laser endomicroscopy in the evaluation of inflammatory bowel disease. Inflamm Bowel Dis 2019;25:1302-1312.

9. Zhang MM, Zhong N, Wang X, et al. Endoscopic ultrasound-guided needle-based confocal laser endomicroscopy for diagnosis of gastric subepithelial tumors: a pilot study. Endoscopy 2019;51:560-565. 
10. Pohl H, Tanczos BT, Rudolph B, et al. Probe-based confocal laser microscopy identifies criteria predictive of active celiac sprue. Dig Dis Sci 2012;57:451-457.

11. Cellvizio ${ }^{\circledR}$ Gastrointestinal Brochure - International [Internet]. Paris: Mauna Kea Technologies; c2016 [cited 2021 June 25]. Available from: https://www.maunakeatech.com/en/researchers/32-brochure.

12. Saadi M, Yu C, Othman MO. A review of the challenges associated with the diagnosis and therapy of primary sclerosing cholangitis. J Clin Transl Hepatol 2014;2:45-52.

13. Hutchins GF, Draganov PV. Cystic neoplasms of the pancreas: a diagnostic challenge. World J Gastroenterol 2009;15:48-54.

14. Gao YD, Qu YW, Liu HF. Comparison of diagnostic efficacy between CLE, tissue sampling, and CLE combined with tissue sampling for undetermined pancreaticobiliary strictures: a meta-analysis. Scand J Gastroenterol 2018;53:482-489.

15. Facciorusso A, Buccino VR, Sacco R. Needle-based confocal laser endomicroscopy in pancreatic cysts: a meta-analysis. Eur J Gastroenterol Hepatol 2020;32:1084-1090.

16. Njei B, McCarty TR, Varadarajulu S, Navaneethan U. Systematic review with meta-analysis: endoscopic retrograde cholangiopancreatography-based modalities for the diagnosis of cholangiocarcinoma in primary sclerosing cholangitis. Aliment Pharmacol Ther 2016;44:1139-1151.

17. Liu Y, Lu Y, Sun B, et al. Probe-based confocal laser endomicroscopy for the diagnosis of undetermined biliary stenoses: a meta-analysis. Clin Res Hepatol Gastroenterol 2016;40:666-673.

18. Fugazza A, Gaiani F, Carra MC, et al. Confocal laser endomicroscopy in gastrointestinal and pancreatobiliary diseases: a systematic review and meta-analysis. Biomed Res Int 2016;2016:4638683.

19. Konjeti VR, McCarty TR, Rustagi T. Needle-based confocal laser endomicroscopy (nCLE) for evaluation of pancreatic cystic lesions: a systematic review and meta-analysis. J Clin Gastroenterol 2022;56:72-80.

20. Peter S, Council L, Bang JY, et al. Poor agreement between endoscopists and gastrointestinal pathologists for the interpretation of probebased confocal laser endomicroscopy findings. World J Gastroenterol 2014;20:17993-18000.

21. Luthra AK, Pusateri AJ, Pfeil SA, et al. Confocal laser endomicroscopy interpretation and differentiation of pancreatic cysts: a randomized trial of teaching modalities. Techniques and Innovations in Gastrointestinal Endoscopy 2021;23:8-17.

22. Gerhards MF, Vos P, van Gulik TM, Rauws EA, Bosma A, Gouma DJ. Incidence of benign lesions in patients resected for suspicious hilar obstruction. Br J Surg 2001;88:48-51.

23. Shah RJ, Langer DA, Antillon MR, Chen YK. Cholangioscopy and cholangioscopic forceps biopsy in patients with indeterminate pancreaticobiliary pathology. Clin Gastroenterol Hepatol 2006;4:219-225.

24. Meining A, Chen YK, Pleskow D, et al. Direct visualization of indeterminate pancreaticobiliary strictures with probe-based confocal laser endomicroscopy: a multicenter experience. Gastrointest Endosc 2011;74:961-968.

25. Wallace M, Lauwers GY, Chen Y, et al. Miami classification for probebased confocal laser endomicroscopy. Endoscopy 2011;43:882-891.

26. Caillol F, Filoche B, Gaidhane M, Kahaleh M. Refined probe-based confocal laser endomicroscopy classification for biliary strictures: the Paris Classification. Dig Dis Sci 2013;58:1784-1789.

27. Wang KK, Carr-Locke DL, Singh SK, et al. Use of probe-based confocal laser endomicroscopy (pCLE) in gastrointestinal applications. A consensus report based on clinical evidence. United European Gastroenterol J 2015;3:230-254.

28. ASGE Standards of Practice Committee, Chathadi KV, Chandrasekhara $\mathrm{V}$, et al. The role of ERCP in benign diseases of the biliary tract. Gastrointest Endosc 2015;81:795-803.

29. Tringali A, Lemmers A, Meves V, et al. Intraductal biliopancreatic imaging: european society of gastrointestinal endoscopy (ESGE) technology review. Endoscopy 2015;47:739-753.

30. Heif M, Yen RD, Shah RJ. ERCP with probe-based confocal laser en- domicroscopy for the evaluation of dominant biliary stenoses in primary sclerosing cholangitis patients. Dig Dis Sci 2013;58:2068-2074.

31. Caillol F, Bories E, Autret A, et al. Evaluation of pCLE in the bile duct: final results of EMID study : pCLE: impact in the management of bile duct strictures. Surg Endosc 2015;29:2661-2668.

32. Slivka A, Gan I, Jamidar P, et al. Validation of the diagnostic accuracy of probe-based confocal laser endomicroscopy for the characterization of indeterminate biliary strictures: results of a prospective multicenter international study. Gastrointest Endosc 2015;81:282-290.

33. Dubow M, Tatman PD, Shah RJ. Individual probe based confocal laser endomicroscopy criteria in the analysis of indeterminate biliary strictures. Scand J Gastroenterol 2018;53:1358-1363.

34. Koda H, Hara K, Nozomi O, et al. High-resolution probe-based confocal laser endomicroscopy for diagnosing biliary diseases. Clin Endosc 2021;54:924-929.

35. Konda VJA, Meining A, Jamil LH, et al. A pilot study of in vivo identification of pancreatic cystic neoplasms with needle-based confocal laser endomicroscopy under endosonographic guidance. Endoscopy 2013;45:1006-1013.

36. Nakai Y, Iwashita T, Park DH, Samarasena JB, Lee JG, Chang KJ. Diagnosis of pancreatic cysts: EUS-guided, through-the-needle confocal laser-induced endomicroscopy and cystoscopy trial: DETECT study. Gastrointest Endosc 2015;81:1204-1214.

37. Napoléon B, Lemaistre A-I, Pujol B, et al. A novel approach to the diagnosis of pancreatic serous cystadenoma: needle-based confocal laser endomicroscopy. Endoscopy 2015;47:26-32.

38. Krishna SG, Hart PA, Malli A, et al. Endoscopic ultrasound-guided confocal laser endomicroscopy increases accuracy of differentiation of pancreatic cystic lesions. Clin Gastroenterol Hepatol 2020;18:432-440. e6.

39. Keane MG, Wehnert N, Perez-Machado M, et al. A prospective trial of CONfocal endomicroscopy in CYSTic lesions of the pancreas: CONCYST-01. Endosc Int Open 2019;7:E1117-E1122.

40. Krishna SG, Hart PA, DeWitt JM, et al. EUS-guided confocal laser endomicroscopy: prediction of dysplasia in intraductal papillary mucinous neoplasms (with video). Gastrointest Endosc 2020;91:551-563.e5.

41. Hao S, Ding W, Jin Y, et al. Appraisal of EUS-guided needle-based confocal laser endomicroscopy in the diagnosis of pancreatic lesions: a single Chinese center experience. Endosc Ultrasound 2020;9:180-186.

42. Chin YK, Wu CCH, Tan DMY. The role of needle-based confocal laser endomicroscopy in the evaluation of pancreatic cystic lesions: a systematic review. Clin Endosc 2021;54:38-47.

43. Giovannini M, Caillol F, Monges G, et al. Endoscopic ultrasound-guided needle-based confocal laser endomicroscopy in solid pancreatic masses. Endoscopy 2016;48:892-898.

44. Orr J, Lockwood R, Roberts J, Shi C, Yachimski P. EUS and confocal endomicroscopic diagnosis of pancreatic acinar cell cystadenoma. Gastrointest Endosc 2018;88:769-770.

45. ASGE Standards of Practice Committee, Muthusamy VR, Chandrasekhara $\mathrm{V}$, et al. The role of endoscopy in the diagnosis and treatment of cystic pancreatic neoplasms. Gastrointest Endosc 2016;84:1-9.

46. European Study Group on Cystic Tumours of the Pancreas. European evidence-based guidelines on pancreatic cystic neoplasms. Gut 2018;67:789-804.

47. Larghi A, Crinò SF, Napoleon B. Pancreatic cystic lesions: time to move to 19-gauge needle with EUS-guided microforceps biopsy or needle-based confocal laser endomicroscopy. Gastrointest Endosc 2020;92:222.

48. Bhutani MS, Koduru P, Joshi V, et al. EUS-guided needle-based confocal laser endomicroscopy: a novel technique with emerging applications. Gastroenterol Hepatol (NY) 2015;11:235-240.

49. Yang D, Samarasena JB, Jamil LH, et al. Endoscopic ultrasound-guided through-the-needle microforceps biopsy in the evaluation of pancreatic cystic lesions: a multicenter study. Endosc Int Open 2018;6:E1423-E1430. 
50. Karia K, Waxman I, Konda VJ, et al. Needle-based confocal endomicroscopy for pancreatic cysts: the current agreement in interpretation. Gastrointest Endosc 2016;83:924-927.

51. Talreja JP, Sethi A, Jamidar PA, et al. Interpretation of probe-based confocal laser endomicroscopy of indeterminate biliary strictures: is there any interobserver agreement? Dig Dis Sci 2012;57:3299-3302.
52. Aubreville M, Stoeve M, Oetter N, et al. Deep learning-based detection of motion artifacts in probe-based confocal laser endomicroscopy images. Int J Comput Assist Radiol Surg 2019;14:31-42.

53. Rasti P, Wolf C, Dorez H, et al. Machine learning-based classification of the health state of mice colon in cancer study from confocal laser endomicroscopy. Sci Rep 2019;9:20010. 